\title{
SALPA MAXIMA.
}

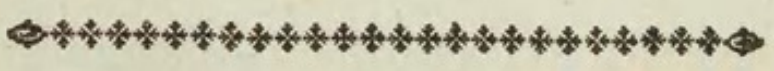

\section{CHARACTER GENERICUS.}

Corpus liberum, gelatinofum, utroque apice apertum, intus vacuum: inteftino obliquo.

$$
\text { Lin. Syft. Nat. Gmel. p. } 3129 .
$$

CHARACTER SPECIFICUS, Eेc.

SALPA utroque apice appendiculato.

Lin. Syft. Nat. Gmel. p. 3129 :

Forfk. Fn. Aegypt. Arab. p. 12. n. 130.

A quo tempore publicata eft fyftematis Linnæani duodecima editio, auctus eft in tantum zoologiæ campus, ut in plerifque animalium divifionibus, in nullis vero magis quam in Mollufcis nova genera inftituere neceffe effet. Inter hæc eminet genus Salpa, quod animalia continet forma, ut plurimum, fubquadrata et elongata, quorum corpus tubulatum et gelatum, apice utroque aperto, vifcerum ramoforum veftigia fubobfcura intus oftendit: quæ tamen in nonnullis fpeciebus evidentius cernuntur. Gregatim eunt Salpæ, celerrime natantes, poffuntque extremitates utrafque ad libitum vel contrahere vel dilatare. Perlucidæ admodum funt, et interdum fplendide 
fplendide varieque verficolores. Multas fæpe cernere eft fibi invicem adhærentes, lateribus conjunctis.

Videtur fumma effe affinitas Salparum generi cum Dagyzis, primo detectis a Jofepho Banks, et Solandro, prope littora Hifpanica. Poffent fortaffe hæc duo genera recte fatis confociari. Salpæ fere omnes in mari Mediterraneo nafcuntur. 



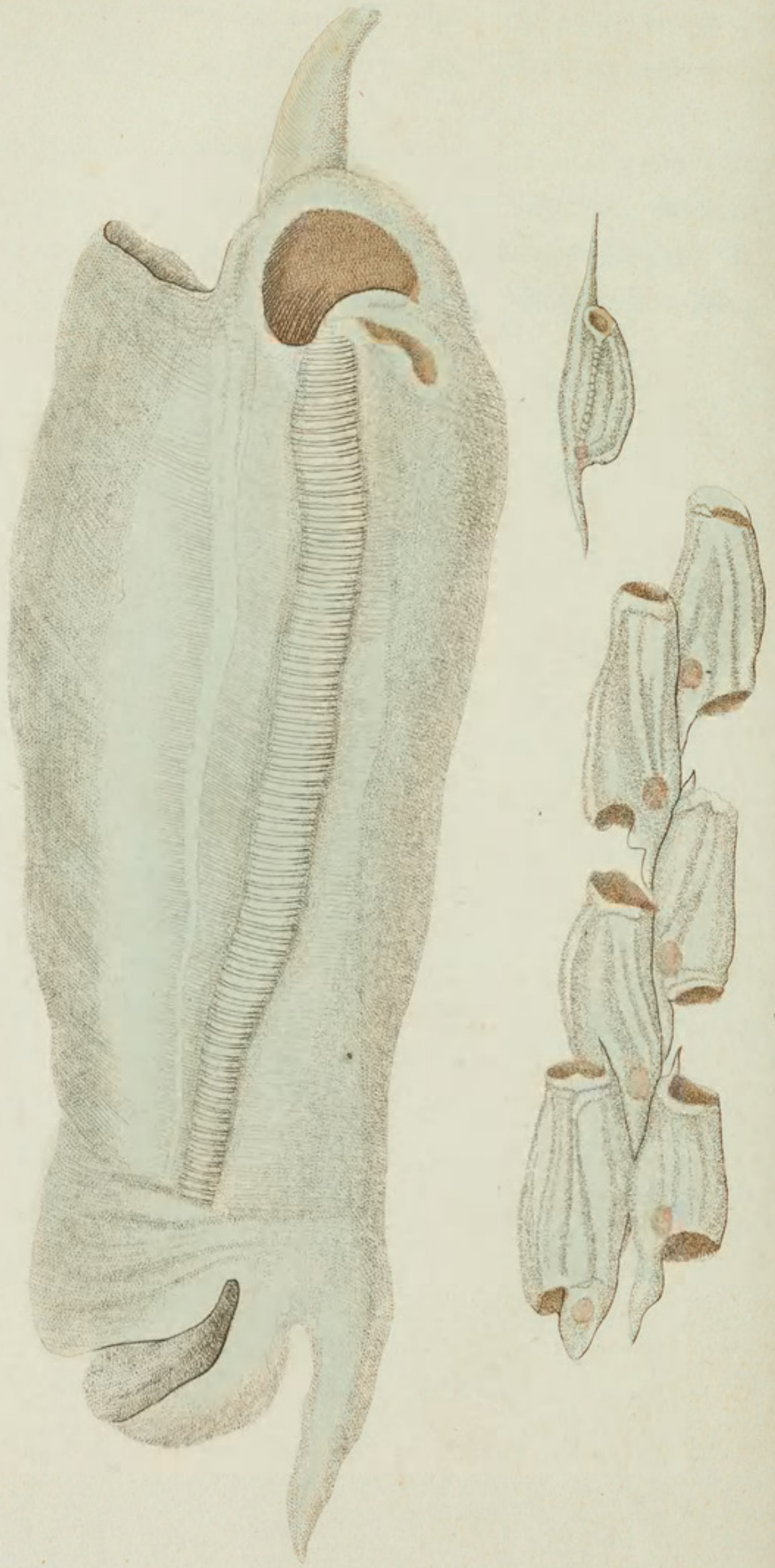


THE

\section{GREAT SALPA.}

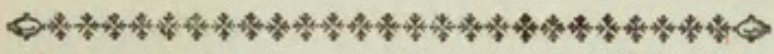

\section{GENERIC CHARACTER.}

Body tubular, nayant, open at each extremity, furnifhed with an oblique intertine.

\section{SPECIFIC CHARACTER.}

SALPA with an appendicle at each extremity.

The field of zoology has been fo much enlarged by the difcoveries made fince the twelfth edition of the Syftema Naturæ of Linnæus, that it has been found neceffary to inftitute a variety of new genera in moft of the divifions of the animal kingdom. In the divifion Mollufca thefe new genera are particularly confpicuous, and form not the leaft curious additions to the hiftory of Nature. The genus Salpa may be numbered amongft the moft ftriking. The Salpæ, in general, are of an elongated and fomewhat fquarifh form, and confift of an oblong, tubular body, open at each extremity, and marked in the interior ftructure with fome obfcure appearance of ramified vifcera; which are much more apparent in fome fpecies than in others. They are of a gregarious nature, and fwim with great facility: porfeffing 
feffing the power of contracting or opening at pleas fure the cavity of their extremities; they are very tranfparent, and fometimes exhibit a rich appearance of varying colors. Several are frequently found adhering clofely together in a lateral direction. It may not be improper to add that the animals of the genus Salpa feem extremely nearly allied to thofe of the genus Dagyza, firft difcovered by Sir Jofeph Banks and Dr. Solander, near the coafts of Spain. Perhaps the two genera of Salpa and Dagyza might. be incorporated without any violation of propriety: the Salpæ, in general, are natives of the Mediterranean fea. 


\section{$2 \mathrm{BHL}$ Biodiversity Heritage Library}

Shaw, George. 1796. "The Great Salpa, Salpa maxima [PI. 232]." The Naturalist's Miscellany 7(LXXVIII), https://doi.org/10.5962/p.310775.

View This Item Online: https://www.biodiversitylibrary.org/item/276356

DOI: https://doi.org/10.5962/p.310775

Permalink: https://www.biodiversitylibrary.org/partpdf/310775

\section{Holding Institution}

Museums Victoria

\section{Sponsored by}

Atlas of Living Australia

\section{Copyright \& Reuse}

Copyright Status: Public domain. The BHL considers that this work is no longer under copyright protection.

This document was created from content at the Biodiversity Heritage Library, the world's largest open access digital library for biodiversity literature and archives. Visit BHL at https://www.biodiversitylibrary.org. 